O.M. Lisova, S.M. Makhno, G.M. Gunya, P.P. Gorbyk

\title{
ELECTROPHYSICAL PROPERTIES OF CARBON NANOTUBES/NiCo COMPOSITES
}

\author{
Chuiko Institute of Surface Chemistry of National Academy of Sciences of Ukraine \\ 17 General Naumov Str., Kyiv, 03164,Ukraine,E-mail: oksana.garkusha@gmail.com
}

\begin{abstract}
Metal-containing nanocomposites containing nanoparticles of organic and inorganic materials, attract considerable attention of specialists in recent years due to a large number of possible applications.

NiCo nanoparticles have been obtained on the surface of unoxidized and oxidized multiwall carbon nanotubes (MWCNT) by chemical precipitation of the corresponding carbonates from a solution of hydrazine hydrate at a temperature of $350 \mathrm{~K}$. Oxidation of MWCNT was carried out in a solution of potassium dichromate and sulfuric acid.

The purpose of this work is to synthesize composites of MWCNT/NiCo and to find differences in their electrophysical properties dependent on the nature of the MWCNT surface.

The transmission electron microscopic and radiographic studies showed the presence of phases composites with the size of crystallites of 20-30 nm. The packing density of agglomerates of metal particles is higher in composites with unoxidized MWCNT. The metal particles are arranged on the surface of MWCNT more evenly and in shape more close to spherical in composites with oxidized MWCNT.

The method of thermogravimetric analysis shows that the process of composites oxidation during heating for a composite containing oxidized MWCNT is more intense. It indicates a smaller particle size of metals.

The real and imaginary components of the complex dielectric and magnetic permeabilities of the disperse composites was determined by the methods of ultrahigh-frequency interferometry. The corresponding values are somewhat higher for composites containing oxidized MWCNT in the ultrahigh-frequency range. The values of imaginary magnetic permeability are higher by $18 \%$ for unoxidized MWCNT composites at low frequencies. The electrical conductivity at low frequencies is 2.9 and $1.6 \mathrm{Ohm}^{-1} \cdot \mathrm{cm}^{-1}$ for composites containing unoxidized and oxidized MWCNTs, respectively.
\end{abstract}

Keywords: multiwall carbon nanotubes, nanocomposites, complex dielectric and magnetic permeability, ultrahigh-frequency range

\section{INTRODUCTION}

Metal-containing nanocomposites containing nanoparticles (NP) of organic and inorganic materials attract considerable attention of specialists in recent years $[1,2]$ due to a large number of possible applications [3]. Promising areas for the introduction of such structures are catalysis and electrocatalysis [4,5]. In electronics, such composites are used as electrode materials for solar and fuel cells [6,7], electric and biosensors $[8,9]$, as well as anticorrosion coatings and much more. They acquire the best catalytic, thermal, optical, electrical, and magnetic properties in comparison with monometallic and bimetallic particles without the presence of a matrix. Consequently, the presence of a matrix not only plays the role of a substrate, but is a functionally active element [10]. Composites are obtained on the surface of various inorganic (kaolin, zeolites and zirconium) and organic (artificial and natural polymers, graphite-derived materials) matrices $[1,5,11,12]$.

Multiwall carbon nanotubes (MWCNT) have become widespread as component parts in nanocomposites, since they have unique mechanical, thermal and electrophysical properties. MWCNTs can be used for microwave absorption of electromagnetic radiation due to high conductivity, porous and multilayer structure, a large specific surface area and a significant ratio of length/diameter, etc. [13].

The importance of finding new methods for obtaining and researching composites is due to their multifunctionality, capability to combine the properties of individual materials in one $[3,14]$. Most often, bimetallic NPs are obtained at the same time as the restoration of two metal ions under conditions of stabilization of the chemical composition, size, and shape of particles. NPs have different forms, they exist in the form of alloys or contact agglomerates, such as kernel-shell, etc. 
The purpose of this work is to synthesize composites of MWCNT/NiCo and to find differences in their electrophysical properties dependent on the nature of the MWCNT surface.

\section{MATERIALS AND METHODS}

The MWCNT was manufactured by the CVD method at the factory «TM Spetsmash» according to TU-U 03291669-009:2009. The $\mathrm{NiCo}$ particles were obtained by chemical precipitation of nickel and cobalt carbonate from a solution of hydrazine dihydrate [15] at the temperature of $350 \mathrm{~K}$. Oxidation of MWCNT was carried out in a solution of ammonium of potassium dichromate and sulfuric acid [13]. For the synthesis of MWCNT/NiCo composites, the technique was modified: co-precipitation of a solution of carbonates and a suspension of nanotubes at a boiling point of hydrazine hydrate at a mass ratio of components of $8: 1$. The addition of $\mathrm{KOH}$ in a suspension of nanotubes created appropriate conditions for the synthesis of metal particles. By adding MWCNT centers of crystallization are created, stabilizing the size and chemical composition of nanoparticles.

Two different types of MWCNT/NiCo composites were synthesized: with unoxidized and oxidized multiwall carbon nanotubes.

Before synthesis, the MWCNT suspension was pre-treated with an ultrasound disperser.

$\mathrm{X}$-ray diffraction analysis was performed by powder diffractometry on a DRON-4-07 diffractometer while the emission of an anode line $\mathrm{Co} K_{\alpha}$ with a nickel filter in the reflected beam at the geometry of the Breguet-Bretagne shooting. The morphology of the specimens was studied using a JEOL JEM-1230 transmitted electron microscope.

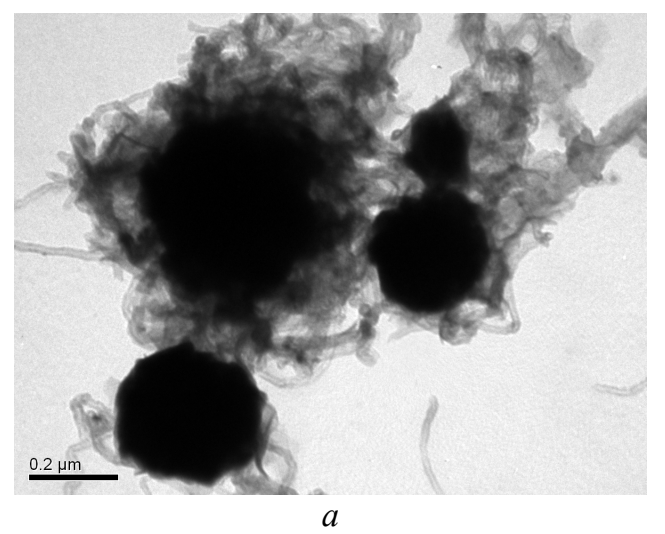

Investigation of the real $\left(\varepsilon^{\prime}\right)$ and the imaginary $\left(\varepsilon^{\prime \prime}\right)$ components of the complex dielectric permittivity of composites was made in ultra-high frequency (UHF) ranging $8-12 \mathrm{GHz}$ and using an interferometer RFK-18 which was based on measuring the phase difference. Standing wave ratio and the weakening of P2-60 by the no-electrode method. And the conductivity was found at low frequencies of $0.1,1$ and $10 \mathrm{kHz}$ with two-contact method using an immittance meter E7-14 [17]. The relative error of $\varepsilon^{\prime}, \varepsilon^{\prime \prime}, \sigma, \mu^{\prime}, \mu^{\prime \prime}$ did not exceed $\pm 5 \%$.

The thermogravimetric measurements, namely mass loss (TG) and differential thermal analysis (DTA), were performed using a Derivatograph Q-1500 D (Hungary) device in a static air atmosphere. A sample weighing $100 \mathrm{mg}$ was heated in a ceramic crucible from room temperature to $1250 \mathrm{~K}$ at the rate of $10 \mathrm{~K} / \mathrm{min}$.

\section{EXPERIMENTAL RESULTS AND DISCUSSION}

Transmission electron microscopy was used to study the size and shape of composites.

It is shown that there are metal particles with the size of $\approx 20-220 \mathrm{~nm}$ (Fig. 1) on the MWCNT surface; in more detailed images on nanotubes, metal particles of $20 \mathrm{~nm}$ can be observed. Probably large particles are agglomerates consisting of small ones [16]. In composites with non-oxidized MWCNT, the density of packaging of agglomerates of metal particles is higher, in composites with oxidized MWCNT, particles are arranged on the surface of MWCNT more evenly and differ in shape more closely related to the spherical one.

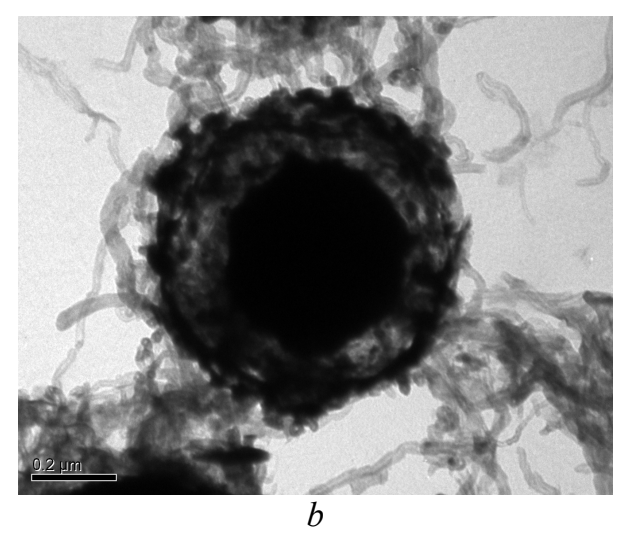

Fig. 1. TEM images of of MWCNT/NiCo composites with unoxidized $(a)$ and oxidized $(b)$ nanotubes 
The results of the X-ray diffraction (Fig. 2) indicate the presence of MWCNT, nickel, and cobalt phases as well as the absence of reflexes of incoming carbonates. Low intensity peak at $30.4^{\circ}$ indicates the presence of nanotubes [18]. Particles of nickel may correspond to peaks of $44.9^{\circ}$ - octahedral (111), 52.2 and $91.8^{\circ}$ - cubic systems.

The cobalt crystalline lattice of a cubic system correspond to peaks of $52.2^{\circ}(111) ; 61.2^{\circ}$ (200); $91.8^{\circ}(220)$; hexagonal $-55.9^{\circ}(101)$. So the peaks of $52.2^{\circ}$ and $91.8^{\circ}$ may indicate the presence of bimetallic Ni-Co particles with cubic crystal lattice (200) [16]. The average crystallite size calculated by Scherrer's equation is 21 and $25 \mathrm{~nm}$ for oxidized and unoxidized MWCNTs, respectively. The intensity of the peaks relative to the metals is somewhat higher for unoxidized nanotubes, which also indicates a larger crystallite size.

The electrophysical characteristics are presented in the Table.

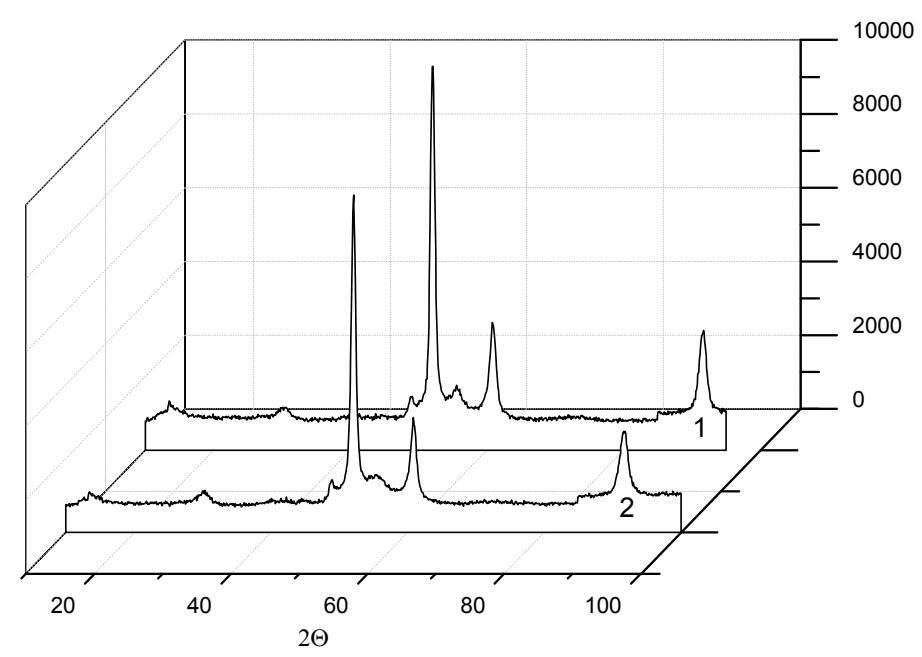

Fig. 2. The composites diffraction of MWNT/NiCo: unoxidized MWCNT (1), oxidized MWCNT (2)

Table. The electrophysical characteristics of MWCNT/NiCo composites

\begin{tabular}{|c|c|c|c|c|c|c|c|}
\hline & \multicolumn{4}{|c|}{ On frequency $8 \mathrm{GHz}$} & \multicolumn{3}{|c|}{ On frequency $1 \mathrm{kHz}$} \\
\hline & \multicolumn{2}{|c|}{$\begin{array}{l}\text { Dielectric } \\
\text { permittivity }\end{array}$} & \multicolumn{2}{|c|}{$\begin{array}{c}\text { Magnetic } \\
\text { permeability }\end{array}$} & \multirow{2}{*}{$\begin{array}{l}\text { Specific electrical } \\
\text { conductivity } \sigma \\
\mathrm{Ohm}^{-1} \mathbf{c m}^{-1}\end{array}$} & \multicolumn{2}{|c|}{$\begin{array}{c}\text { Magnetic } \\
\text { permeability }\end{array}$} \\
\hline & $\varepsilon^{\prime}$ & $\varepsilon^{\prime \prime}$ & $\mu^{\prime}$ & $\mu^{\prime \prime}$ & & $\mu^{\prime}$ & $\mu^{\prime \prime}$ \\
\hline $\begin{array}{l}\text { Unoxidized } \\
\text { MWCNT/NiCo }\end{array}$ & 7.3 & 6.4 & 2.6 & 2.2 & 2.9 & 25.3 & 0.33 \\
\hline $\begin{array}{l}\text { Oxidized } \\
\text { MWCNT/NiCo }\end{array}$ & 7.6 & 6.9 & 3.2 & 2.6 & 1.6 & 25.2 & 0.27 \\
\hline
\end{tabular}

The value of electrical conductivity of composites with oxidized MWCNT at $1 \mathrm{kHz}$ is lower in comparison with those of samples with unoxidized MWCNT, but it has better magnetic losses at microwave range. At low frequencies, the level of magnetic losses is somewhat lower for composites containing oxidized MWCNT, which is obviously due to the smaller size of metal nanoparticles. The electrophysical characteristics of the systems under consideration do not depend on the frequency within the limits of the error, in the frequency range of $0.1-10 \mathrm{kHz}$.

A thermogravimetric analysis method (TGA) was used to investigate the properties of composites (Fig. 3).

As see on TGA data (Fig. $3 b$ ) the oxidation process during heating of composite containing oxidized MWCNT is more intense, this is probably due to the smaller size of metal particles. The oxidation process of this system begins and ends at lower temperatures. From 
[17] it is known that the process of oxidation of nanotubes takes place in the temperature range of $450-900{ }^{\circ} \mathrm{C}$, these limits can differ $\pm 30{ }^{\circ} \mathrm{C}$ as dependent on the type of nanotubes and the method of their obtaining. Consequently, a sharp

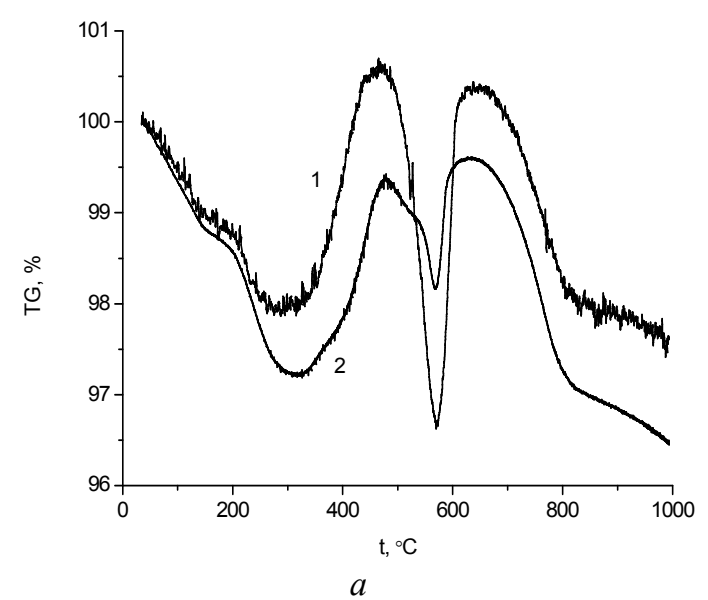

decrease from 470 to $600{ }^{\circ} \mathrm{C}$ for both composites (Fig. $3 a$ ) on the mass loss curve (TG) can be explained by the oxidation of nanotubes, after $600{ }^{\circ} \mathrm{C}$ the metal oxidation process predominates.

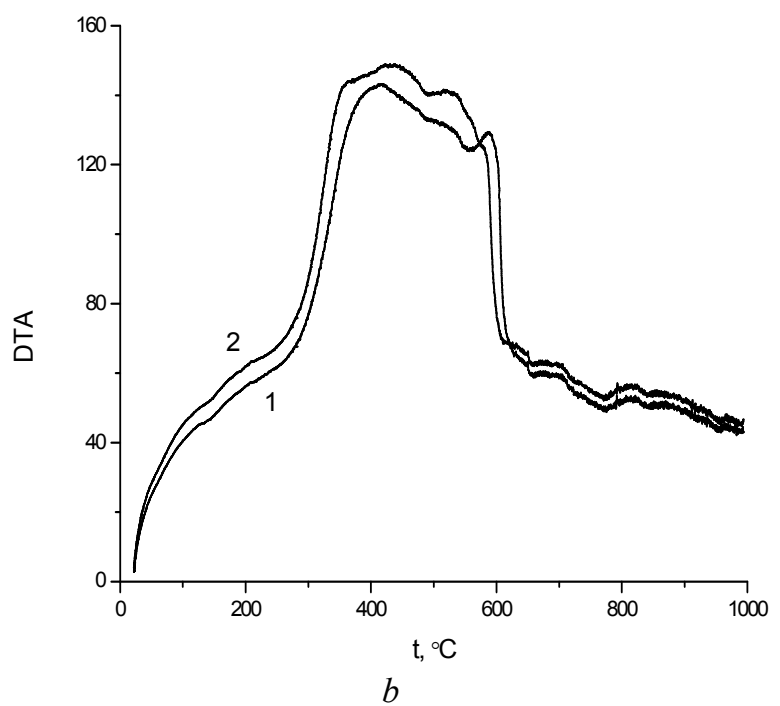

Fig. 3. TG $(a)$ and TGA (b) MWCNT/NiCo composites: unoxidized MWCNT (1), oxidized MWCNT (2) as function of temperature

\section{CONCLUSIONS}

NiCo nanoparticles were obtained on the surface of unoxidized and oxidized multiwall carbon nanotubes (MWCNT) by chemical precipitation of the corresponding carbonates from a solution of hydrazine hydrate The transmithion electron microscopic and radiographic studies have shown the presence of phases composites with the size of crystallites of 20-30 nm, the large particles are agglomerates consisting of small ones. The packing density of agglomerates of metal particles is higher in composites with unoxidized MWCNT. The metal particles are arranged on the surface of MWCNT more evenly and in shape more close to spherical in composites with oxidized MWCNT.
The real and imaginary components of the complex dielectric and magnetic permeabilities of the disperse composites was determined by the methods of ultrahigh-frequency interferometry. The corresponding values are somewhat higher for composites containing oxidized MWCNT in the ultrahigh-frequency range. At low frequencies, the level of magnetic losses is somewhat lower for composites containing oxidized MWCNT, which is obviously due to the smaller size of metal nanoparticles.

The method of thermogravimetric analysis shows that the process of composites oxidation during heating for a composite containing oxidized MWCNT is more intense. It indicates a smaller particle size of metals. 


\title{
Електрофізичні властивості композитів вуглецеві нанотрубки/ NiCo
}

\author{
О.М. Лісова, С.М. Махно, Г.М. Гуня, П.П. Горбик
}

Інститут хімії поверхні ім. О.О. Чуйка Національної академії наук Украӥни вул. Генерала Наумова, 17, Київ, 03164, Україна, oksana.garkusha@gmail.com

Одержано наночастинки NiCo на поверхні неокиснених та окиснених багатошарових вуглецевих нанотрубок (БВНТ) методом хімічного осадження відповідних карбонатів з розчину гідразингідрату, за температури його кипіння. Окиснення БВНТ проводили в розчині біхромату калію та сірчаної кислоти.

Метою роботи є синтез композитів БВНT/NiCo та встановлення відмінностей їх електрофізичних властивостей в залежності від природи поверхні БВНТ.

Проведені електронно-мікроскопічні та рентгенографічні дослідження показали присутність фаз композитів нанометрового розміру з розміром кристалітів 20-30 нм. В композитах з неокисненими БВНТ, щільність упаковки агломератів металевих частинок вища, в композитах з окисненими БВНТ частинки розташовані по поверхні БВНТ рівномірніше і відрізняються формою, більш близькою до сферичної.

Методом диференціально-термічного аналізу показано, щуо для композита, який містить окиснені БВНТ, процес окиснення композитів при нагріванні відбувається більш інтенсивно, щзо також вказує на менший розмір частинок металів. Методами надвисокочастотної інтерферометрії визначено дійсні та уявні складові комплексних діелектричної та магнітної проникностей дисперсних композитів. Для композитів, щзо містять окиснені БВНТ, відповідні значення є дещзо вищими в надвисокочастотному діапазоні. На низьких частотах значення уявної магнітної проникності є вищими на $18 \%$ для композитів 3 неокисненими БВНТ, а електропровідності дорівнюють $2.9 \mathrm{ma} 1.6 \mathrm{OM}^{-1} \mathrm{~cm}^{-1}$ для композитів, щзо містять неокиснені та окиснені БВНТ відповідно. Відмінність характеристик може бути пов'язана з додатковою обробкою БВНТ і наявністю значної кількості функиіональних зв'язків на поверхні.

Ключові слова: багатошарові вуглецеві нанотрубки, нанокомпозити, комплексні діелектрична та магнітна проникності, надвисокочастотний діапазон

\section{Электрофизические свойства композитов углеродные нанотрубки/NiCo}

\author{
О.М. Лисова, С.Н. Махно, Г.М. Гуня, П.П. Горбик
}

Институт химии поверхности им. А.А. Чуйка Наџиональной академии наук Украины ул. Генерала Наумова, 17, Киев,03164, Украина, oksana.garkusha@gmail.com

Наночастицы NiCo были получены на поверхности неокисленных и окисленных многослойных углеродных нанотрубок (МУНТ) методом химического осаждения соответствуюших карбонатов из раствора гидразингидрата, при температуре его кипения. Окисление МУНТ проводили в растворе бихромата калия и серной кислотыл.

Цель работы - синтезировать композиты MУHT/NiCo и выявить отличия двух систем в зависимости от природы поверхности МУНТ.

Проведенные электронно-микроскопические и рентгенографические исследования показали присутствие фаз композитов нанометрового размера с размером кристаллитов 20-30 нм. В композитах с неокисленными МУНТ, плотность упаковки агломератов металлических частиц выше, в композитах с окисленной МУНТ частицы расположены по поверхности МУНТ равномернее и отличаются формой, более близкой к сферической.

Методом дифференциально-термического анализа показано, что для композита, который содержит окисленные МУНТ, процесс окисления композитов при нагревании происходит более интенсивно, что также указывает на меньший размер частии металлов. Методами сверхвысокочастотной интерферометрии определены действительные и мнимые составляющие комплексных диэлектрической и магнитной проницаемостей дисперсных композитов. Для композитов, содержащих окисленные МУНТ, соответствующие значения несколько выше в сверхвысокочастотном диапазоне. На низких частотах значение мнимой магнитной проницаемости выше на $18 \%$ для композитов с неокисленными МУНТ, а 
электропроводности равны 2.9 и $1.6 \mathrm{OM}^{-1} \mathrm{~cm}^{-1}$ для композитов, содержащих неокисленные и окисленные МУНТ соответственно. Отличие характеристик может быть связано с дополнительной обработкой МУНТ и наличием значительного количества функииональных связей на поверхности.

Ключевые слова: многослойные углеродные нанотрубки, нанокомпозиты, комплексные диэлектрическая и магнитная проницаемости, сверхвысокочастотный диапазон

\section{REFERENCES}

1. Sharma G., Naushad M., Kumar A., Devi S., Khan M.R. Lanthanum/Cadmium/Polyaniline bimetallic nanocomposite for the photodegradation of organic pollutant. Iran. Polym. J. 2015. 24(12): 1003.

2. Sharma G., Kumar D., Kumar A., Al-Muhtaseb A.H., Pathania D., Naushad M., Mola G.T. Revolution from monometallic to trimetallic nanoparticle composites, various synthesis methods and their applications: a review. Mater. Sci. Eng. C. 2017. 71: 1216.

3. Hamidi S.M., Mosaeii B., Afsharnia M., Aftabi A., Najafi M. Magneto-plasmonic study of aligned Ni, Co and $\mathrm{Ni} / \mathrm{Co}$ multilayer in polydimethylsiloxane as magnetic field sensor. J. Magn. Magn. Mater. 2016. 417: 413.

4. Han Y., Li W., Zhang M., Tao K. Catalytic dechlorination of monochlorobenzene with a new type of nanoscale $\mathrm{Ni}$ (B)/Fe (B) bimetallic catalytic reductant. Chemosphere. 2008. 72(1): 53.

5. Habibi B., Ghaderi S. Synthesis, characterization and electrocatalytic activity of Co@Pt nanoparticles supported on carbon-ceramic substrate for fuel cell applications. Int. J. Hydrogen Energy. 2015. 40(15): 5115.

6. Motlak M., Barakat N.A.M., Akhtar M.S., Hamza A.M., Kim B., Sang C., Abdelrazek K., Almajid A.A. High performance of NiCo nanoparticles-doped carbon nano fi bers as counter electrode for dye-sensitized solar cells. Electrochim. Acta. 2015. 160: 1.

7. Dao V., Choi Y., Yong K., Larina L.L., Shevaleevskiy O., Choi H. A facile synthesis of bimetallic AuPt nanoparticles as a new transparent counter electrode for quantum-dot-sensitized solar cells. J. Power Sources. 2015. 274: 831 .

8. Cui M, Huang J., Wang Y., Wu Y., Luo X. Molecularly imprinted electrochemical sensor for propyl gallate based on PtAu bimetallic nanoparticles modified graphene - carbon nanotube composites. Biosens. Bioelectron. 2015. 68: 563.

9. Kung C., Lin P., John F., Xue Y, Yu X. Preparation and characterization of three dimensional graphene foam supported platinum - ruthenium bimetallic nanocatalysts for hydrogen peroxide based electrochemical biosensors. Biosens. Bioelectron. 2014. 52:1.

10. Awasthi S., Pandey S.K., Juyal A., Pandey C.P., Balani K. Synergistic effect of carbonaceous reinforcements on microstructural, electrochemical, magnetic and tribological properties of electrophoretically deposited nickel. J. Alloys Compd. 2017. 711: 424.

11. Ahmad A., Qureshi A.S., Li L., Bao J., Jia X., Xu Y., Guo X. Antibacterial activity of graphene supported FeAg bimetallic nanocomposites. Colloids Surf. B Biointerfaces. 2016. 143: 490.

12. Lisova O.M., Makhno S.M., Gunya G.M., Gorbyk P.P. Synthesis of the composites of grapheme nanoplatelets/(Ni-Co) and their properties. Him. Fiz. Tehnol. Poverhni. 2017. 8(4): 393.

13. Kovalska E.O., Sementsov Yu.I., Kartel M.T., Prikhod'ko G.P. Synthesis of catalysts for growth of carbon nanotubes and testing their effectiveness. Him. Fiz. Tehnol. Poverhni. 2012. 3(3): 335.

14. Lisova O.M., Abramov M.V., Makhno S.M., Gorbik P.P. Synthesis and Magnetic Characteristics of Ni-Co Nanocomposites. Metallofizika i noveishie tekhnologii. 2018. 40(5): 561.

15. Lapsina P.V. Ph. D (Chem.) Thesis. (Kemerovo, 2013). [in Russian].

16. Hanyuk L.M., Ihnatkov V.D., Makhno S.M., Soroka P.M. Study of the dielectric properties of the fibrous material. Ukr. fiz. zhurn. 1995. 40(6): 627. [in Ukrainian].

17. Sementsov Yu.I., Makhno S.M., Zhuravsky S.V., Kartel M.T. Properties of polyethylene-carbon nanotubes composites. Him. Fiz. Tehnol. Poverhni. 2017. 8(2):107. [in Ukrainian]. 